5 Géssica de O. S. Santos ${ }^{a, b, c}$, Katlin I. B. Eguiluz ${ }^{a, b}$; Giancarlo R. Salazar-Banda ${ }^{a, b}$; Cristina

\section{Testing the role of electrode materials on the Electro-Fenton and}

\section{Photoelectro-Fenton degradation of Clopyralid}

6

7

8

9

10

11

12

\section{7}

${ }^{a}$ Electrochemistry and Nanotechnology Laboratory, Research and Technology Institute (ITP), Aracaju, SE, Brazil

${ }^{b}$ Processes Engineering Post-graduation (PEP), Universidade Tiradentes, 49037-580

Aracaju, SE, Brazil

${ }^{c}$ Department of Chemical Engineering, Universidad de Castilla-La Mancha, Campus Universitario s/n, 13071 Ciudad Real, Spain

*Author to whom all correspondence should be addressed: manuel.rodrigo@uclm.es 
This work studies the effect of the anode and cathode materials on the degradation of the herbicide clopyralid. Different electrochemical advanced oxidation processes (EAOPs), including electrochemical oxidation with electrogenerated hydrogen peroxide $\left(\mathrm{EO}-\mathrm{H}_{2} \mathrm{O}_{2}\right)$, electro-Fenton (EF), and photoelectro-Fenton (PEF) were carried out. The first experiments were focused on the effect of the cathode, where the use of the hydrophobic carbon felt modified by the deposition of carbon black \& PTFE mixture (MCF) improves the $\mathrm{H}_{2} \mathrm{O}_{2}$ production in comparison to a conventional carbon felt $(\mathrm{CF})$, regardless of the anode material employed. On the other hand, a laser-made $\mathrm{Ti} / \mathrm{Ru}_{0.3} \mathrm{Ti}_{0.7} \mathrm{O}_{2}$ mixed metal oxide (MMO) and a commercial boron-doped diamond (BDD) were compared as anodes. Results obtained point out that the MMO anode promotes the accumulation of this oxidant $\left(\mathrm{H}_{2} \mathrm{O}_{2}\right)$ in bulk. Once characterized by the production of hydrogen peroxide, the second part of this study focused on the degradation of clopyralid with the MCF cathode with different EAOPs. Results demonstrate that clopyralid fastly degrades in the sequence $\mathrm{EO}-\mathrm{H}_{2} \mathrm{O}_{2}<\mathrm{EF}<\mathrm{PEF}$, and almost complete mineralization occurs for EF and PEF employing MMO or BDD as the anode. Synergy effect study shows that irradiation of 9 W UVC produces a positive synergistic effect of $81.7 \%$ and $41.55 \%$ (for the PEF-MMO and PEF-BDD, respectively), ascribed to the additional removal of aromatic intermediates by the UVC and the activation of $\mathrm{H}_{2} \mathrm{O}_{2}$. At the end of the treatment, mineralization of the herbicide was attained at $1.22 \mathrm{~kW} \mathrm{~h}\left(\mathrm{~g}^{-1} \mathrm{TOC}\right)$. Finally, considering the lower cost of the prepared MMO, these findings demonstrate the potentiality of using modified carbon felt combined with the laser-made $\mathrm{Ti} / \mathrm{Ru}_{0.3} \mathrm{Ti}_{0.7} \mathrm{O}_{2}$ anode for the treatment of polluted waters. 
52

Highlights

53

54

55

56

57

58

59

60

61

62

63

64

65

- The modified carbon felt allowed achieving higher values of $\mathrm{H}_{2} \mathrm{O}_{2}$

- Perchlorates detected using BDD vary in the sequence $\mathrm{OE}<\mathrm{EF}<\mathrm{PEF}$.

- No perchlorate was detected when working with the $\mathrm{Ti} / \mathrm{Ru}_{0.3} \mathrm{Ti}_{0.7} \mathrm{O}_{2}$.

- Mineralization is achieved only when $\mathrm{Fe}^{2+}$ ions are added in EF and PEF treatments

- Although clopyralid was mineralized with both anodes, MMO is more cost-efficient 
The presence of pesticides in surface and groundwater-related to the use and production of pesticides is of great concern due to the severe environmental impact on the ecosystems and human health [1]. Clopyralid is an organochlorinated herbicide from the class of the pyridine compounds (i.e., pesticides derived from picolinic acid) that have widespread use for control broadleaf weeds and woody plants [2]. Given its recalcitrance and toxicity, many research efforts have been devoted to study effective technologies capable of removing this type of contaminant from aqueous solution [3-7].

Advanced oxidation processes have shown high potential for the removal of organochlorinated compounds due to the in situ generation of highly reactive and nonselective hydroxyl radical $\left({ }^{\bullet} \mathrm{OH}, E^{\mathrm{o}}=2.8 \mathrm{~V} / \mathrm{SHE}\right)$ capable of led complete mineralization of many types of pollutants $[8,9]$. One class of AOPs that has attracted considerable attention is the electrochemical oxidation processes (EAOPs) such as electrochemical oxidation (EO), electro-Fenton (EF), and photoelectro-Fenton (PEF) [10]. The main advantage of the EAOPs is that this kind of technology: 1) can manage a wide range of pollutants and concentrations; 2) can generate $\mathrm{H}_{2} \mathrm{O}_{2}$ in situ; 3) operates at mild conditions and can be easily scalable, and 4) is considered environmentally friendly for wastewater treatment contaminated by persistent or toxic organic pollutants [11]

In the EO, the oxidation ability depends on the anode material used [12]. It is wellknown that BDD anodes are capable of attaining complete mineralization due to the electrogeneration of a high amount of very reactive ${ }^{\bullet} \mathrm{OH}$. Conversely, mixed metal oxides anodes (MMOs), a much cheaper anode option, and are known to allow conversion of organic contaminants into simpler molecules [13]. The combination of EO with cathodic electrogeneration of $\mathrm{H}_{2} \mathrm{O}_{2}$ from $\mathrm{O}_{2}$ reduction (based on the Eq. 1) corresponds to the process named as $\mathrm{EO}-\mathrm{H}_{2} \mathrm{O}_{2}$. On the other hand, the oxidation ability of $\mathrm{H}_{2} \mathrm{O}_{2}$ can be strongly enhanced by 
93

94

95

96

97

the addition of an iron catalyst to the solution and the operation at acidic pHs, which allows getting the Fenton's reaction (Eq. 2) (electro-Fenton process) [11, 14].

$\mathrm{O}_{2}(\mathrm{~g})+2 \mathrm{H}^{+}+2 \mathrm{e}^{-} \rightarrow \mathrm{H}_{2} \mathrm{O}_{2}$

$\mathrm{H}_{2} \mathrm{O}_{2}+\mathrm{Fe}^{2+} \rightarrow \mathrm{Fe}^{3+}+\mathrm{OH}^{-}+{ }^{\bullet} \mathrm{OH}$

This process may be enhanced by UV irradiation, due to the photolysis of $\mathrm{H}_{2} \mathrm{O}_{2}$ molecules producing additional ${ }^{\bullet} \mathrm{OH}$ radicals together with the photodegradation of complexes of $\mathrm{Fe}(\mathrm{III})$ with organic compounds and photodegradation of photoactive $\mathrm{Fe}(\mathrm{OH})^{2+}$ [15]. Most of the published articles focus on the irradiation with UVA $\left(\lambda_{\max }=365 \mathrm{~nm}\right)$ or solar irradiation [16, 17], but only a few papers have dedicated to the application of UVC $\left(\lambda_{\max }=254 \mathrm{~nm}\right)$ in PEF process [18-21]. The UVC light can contribute to the direct photolysis of aromatic molecules. Moreover, with the use of UVC instead of UVA makes the Fenton's reaction (Eq. (1)) less important, because of the prevalence homolysis of $\mathrm{H}_{2} \mathrm{O}_{2}$ to form ${ }^{\bullet} \mathrm{OH}$. It means that PEF with $\mathrm{UVC}$ is similar to the $\mathrm{H}_{2} \mathrm{O}_{2} / \mathrm{UVC}$ process [21]. Moreover, when high quantities of $\mathrm{H}_{2} \mathrm{O}_{2}$ are produced, and the only catalytic amount of $\mathrm{Fe}^{2+}$ is used, an excess of $\mathrm{H}_{2} \mathrm{O}_{2}$ may accumulate, which is detrimental because it acts as a scavenger. Thus, UVC is suitable to produce additional amounts of ${ }^{\bullet} \mathrm{OH}$.

Development of cathode materials capable of ensuring a fast and efficient production of $\mathrm{H}_{2} \mathrm{O}_{2}$ is a crucial feature for a competitive implementation of the technologies mentioned above [22]. For this, the employment of environmentally friendly carbonaceous cathodes has been widely reported [23-31]. Recently, the mixture between carbon black and polytetrafluoroethylene (CB/PTFE) applied to the carbon felt was reported to promote a fast and efficient production of hydrogen peroxide [32]. 
Here we evaluated the mineralization process and decay kinetic of an acid pesticide, clopyralid, using EO, EF, and PEF with a 9 W UVC light employing two types of anodes (i.e., a laser-prepared $\mathrm{Ti} / \mathrm{Ru}_{0.3} \mathrm{Ti}_{0.7} \mathrm{O}_{2}$ [33] and a commercial boron-doped diamond anode). Also, the effect of unmodified and modified carbon-felt as cathode for $\mathrm{H}_{2} \mathrm{O}_{2}$ production was studied. The performance of the processes was analyzed by high-performance liquid chromatography (HPLC), total dissolved organic carbon (TOC), and ionic chromatography (IC).

\section{Experimental section}

\subsection{Materials}

125 Clopyralid (3,6-dichloro-2-pyridine-carboxylic acid, $\mathrm{C}_{6} \mathrm{H}_{3} \mathrm{Cl}_{2} \mathrm{NO}_{2}$ ) purchased from Sigma Aldrich $^{\circledR}$ was of analytical grade (99\%). Oxalic, maleic, and oxamic acids were purchased from Panreac ${ }^{\circledR}$. Heptahydrate ferrous sulfate used as catalyst was also purchased from Panreac $^{\circledR}$ and used as supporting electrolyte. The initial $\mathrm{pH}$ of the synthetic wastewater solution was not adjusted since clopyralid has acid character presenting an initial $\mathrm{pH}$ around 3.4. Ultrapure water (Millipore ${ }^{\circledR}$ Milli-Q system, resistivity $=18.2 \mathrm{M} \Omega \mathrm{cm}$ at $25^{\circ} \mathrm{C}$ ) was used to prepare all solutions. Methanol and formic acid purchased from Sigma-Aldrich ${ }^{\circledR}$ were used as the mobile phase of high-performance liquid chromatography (HPLC). All reactants were used as received.

\subsection{Experimental setup}

The electrolyzes experiments were performed at a laboratory scale with a cylindrical, open, and undivided three-electrode cell of $0.15 \mathrm{~L}$ capacity with a jacket recirculation of water thermostated at $25{ }^{\circ} \mathrm{C}$. A $4 \mathrm{~cm}^{2}$ BDD film, $8000 \mathrm{ppm}$ boron doping, supplied by Adamant 
were employed as anode material. As cathodes, a $60 \mathrm{~cm}^{2}$ unmodified carbon felt (CF) or the modified carbon felt prepared according to a procedure described elsewhere [32] was placed on the inner wall of the cell according to experimental setup proposed elsewhere [35] and fed with air bubbled 10 min prior each experiment. All the experiments were carried out at the constant current of 0.15 A provided by an Autolab (Metrohm - Pensalab) PGSTAT302N potentiostat/galvanostat, controlled by software Nova 2.1 . The solutions were stirred with a magnetic bar at $500 \mathrm{rpm}$ for homogenization. The PEF experiments were conducted by irradiating the solution with a $9 \mathrm{~W}$ UV-C lamp $\left(\lambda_{\max }=254 \mathrm{~nm}\right)$ that was immersed in the solution. A schematic representation of the setup is shown in Figure 1.

(1)

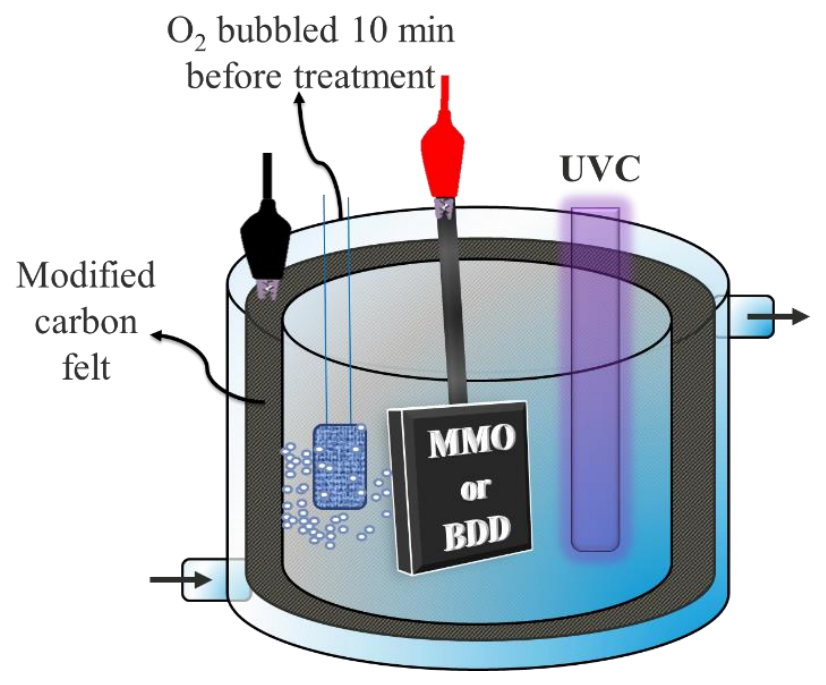

Figure 1. Schematic representation of the system. 


\subsection{Analytical techniques}

The hydrogen peroxide concentration was measured by following the concentration of the complex formed between $\mathrm{H}_{2} \mathrm{O}_{2}$ and $\mathrm{Ti}^{4+}$ [32]. Clopyralid and aromatic intermediates were monitored by high-performance liquid chromatography (HPLC) using an Agilent 1100 series, equipped with an Eclipse Plus C-18 column (4.6 $\mathrm{mm} \times 100 \mathrm{~mm} ; 3.5 \mu \mathrm{m})$ with detection at $280 \mathrm{~nm}$. The mobile phase was water (containing $0.1 \%$ formic acid) $/$ methanol $(70 / 30, \mathrm{v} / \mathrm{v})$ at a flow rate of $1.0 \mathrm{~mL} \mathrm{~min}^{-1}$. The injection volume was $20.0 \mu \mathrm{L}$, the column temperature was set to $20^{\circ} \mathrm{C}$, and the retention time was around 2.7 min for clopyralid. Acids intermediates were identified by HPLC equipped with a Zorbax SB-Aq, column $(4.6 \mathrm{~mm} \times 150 \mathrm{~mm})$, the mobile phase consists of $4 \mathrm{mM} \mathrm{H} \mathrm{H}_{2} \mathrm{SO}_{4}$ with detection at $210 \mathrm{~nm}$. Inorganic ions (nitrite, nitrate, ammonium, chlorate, and perchlorate) concentrations were measured by ion chromatography using a Metrohm 732IC coupled to a conductivity detector. A Metrosep A Supp 4-250 column was used as the stationary phase and $3.6 \mathrm{mM} \mathrm{Na}_{2} \mathrm{CO}_{3}$ /acetonitrile 85:15 $(\mathrm{V} / \mathrm{V})$ as the mobile phase. In the case of $\mathrm{ClO}^{-}$, the determination was carried out by a spectrophotometric method (at $293 \mathrm{~nm}$ ) using a UV-Vis spectrophotometer (Cary Series, Agilent Technologies). The total organic carbon concentration ([TOC]) was monitored using a Multi N/C 3100 Analytik Jena analyzer.

\subsection{Synergy coefficient and energy consumption}

The effect of the combination of EAOPs was investigated through the synergy coefficient (\%) (Eq 3), where $k$ is the kinetic constant fitted from experimental data for the different processes studied. Here, the ratio between the kinetic constant of the combined process and the sum of the kinetic constants of all processes involved is considered [40].

$$
\text { Synergy coefficient }(\%) \times 100=\frac{k_{E F}-k_{E O / H_{2} O_{2}}}{\left(\sum k_{\text {individual }}\right)} \text { or } \frac{k_{P E F}-k_{E F^{-}} k_{\text {photo }}-k_{E O / H_{2} O_{2}}}{\left(\sum k_{\text {individual }}\right)}
$$


The specific energy consumption per unit TOC mass $\left(\mathrm{EC}_{\mathrm{TOC}}\right)$ for the electrochemical

and photochemical process studied was calculated from Eq (4), where $\mathrm{E}_{\text {cell }}$ is the average cell potential in $\mathrm{V}, \mathrm{I}$ is the constant applied current in $\mathrm{A}, \mathrm{t}$ is the electrolysis time in $\mathrm{h}, \mathrm{Vs}$ is the aqueous waste volume in $\mathrm{L}$ and $(\triangle \mathrm{TOC})_{\exp }$ is the TOC removal (in $\mathrm{g} \mathrm{L}^{-1}$ ) [41], and $\mathrm{P}$ is the nominal power of the UVC lamp (W) [42].

$$
E C_{T O C}\left(\mathrm{kWh} g^{-1} \mathrm{TOC}\right)=\left(\frac{E c e l l \cdot \mathrm{I} \cdot \mathrm{t}}{V_{S} \cdot(\Delta T O C)_{\text {exp }}}\right) \text { or }\left(\frac{E c e l l \cdot \mathrm{I} \cdot \mathrm{t}+\mathrm{P} \cdot \mathrm{t}}{V_{s} \cdot(\Delta T O C)_{\text {exp }}}\right)
$$

\section{Results and discussion}

$\mathrm{H}_{2} \mathrm{O}_{2}$ electrochemical generation. A highly-efficient electrogeneration of hydrogen peroxide is essential for getting an efficient electro-Fenton process. Because of that, it was monitored the production of this oxidant with four electrodes: unmodified carbon felt (CF) and modified carbon felt (MCF) used as cathode materials and mixed metal oxide (MMO) and boron-doped diamond (BDD), proposed as anodes. Figure 2a shows the changes in the concentration of $\mathrm{H}_{2} \mathrm{O}_{2}$ with time when applying a fixed current of $37.5 \mathrm{~mA} \mathrm{~cm}$-2 to a $0.05 \mathrm{M}$ $\mathrm{Na}_{2} \mathrm{SO}_{4}$ solution. The production of $\mathrm{H}_{2} \mathrm{O}_{2}$ should occur primarily due to the electrochemical reduction of dissolved oxygen via Eq. (1). The stabilization observed in the $\mathrm{H}_{2} \mathrm{O}_{2}$ accumulation appears after $60 \mathrm{~min}$ for $\mathrm{MMO}-\mathrm{CFM}$ and after $20 \mathrm{~min}$ for BDD-CF, BDDCFM, and MMO-CF and it can be explained in terms of different side reactions that may affect to the produced hydrogen peroxide, promoting its transformation into other species. Thus, $\mathrm{H}_{2} \mathrm{O}_{2}$ may undergo self-decomposition, as indicated in Eqs. (5-7), further cathodic reduction to water, as shown in Eq. (8), or the anodic oxidation to oxygen, as proposed in Eq. (9). All these side reactions have been widely discussed in the existing literature [43-46]. 
$\mathrm{H}_{2} \mathrm{O}_{2} \leftrightarrow \mathrm{HO}_{2}^{-}+\mathrm{H}^{+}$

$\mathrm{H}_{2} \mathrm{O}_{2}+\mathrm{HO}_{2}^{-} \rightarrow \mathrm{H}_{2} \mathrm{O}+\mathrm{O}_{2}+\mathrm{OH}^{-}$

212

$\mathrm{H}_{2} \mathrm{O}_{2}+2 \mathrm{H}^{+}+2 \mathrm{e}^{-} \rightarrow 2 \mathrm{H}_{2} \mathrm{O}$

$\mathrm{H}_{2} \mathrm{O}_{2}-2 \mathrm{e}^{-} \rightarrow \mathrm{O}_{2}+2 \mathrm{H}^{+}$

Interestingly, the employment of the combination MCF-MMO increases 12-times the

$\mathrm{H}_{2} \mathrm{O}_{2}$ production as compared with CF-MMO. On the other hand, an increase of 5-times is observed for MCF-BDD as compared to the CF-BDD. These results agree with those reported by $\mathrm{Yu}$ et al., which pointed out an increase in $\mathrm{H}_{2} \mathrm{O}_{2}$ production after graphite felt modification (with carbon black and polytetrafluoroethylene) and a Pt sheet as the anode, without external aeration [23]. Similarly, Pérez et al. tested modifications of carbon felt employing the precursor solution described by $\mathrm{Yu}$ et al. and found that the utilization of an $\mathrm{MCF}$ as cathode enhanced the generation of $\mathrm{H}_{2} \mathrm{O}_{2}$ in comparison to the unmodified CF [29].

It is also essential to highlight the effect of the anode material in $\mathrm{H}_{2} \mathrm{O}_{2}$ production. The production of $\mathrm{H}_{2} \mathrm{O}_{2}$ is almost 11-times higher when using the MCF-MMO than at the MCF-BDD anode after 90 min of electrolysis. Note that this difference is even significant, considering that the $\mathrm{H}_{2} \mathrm{O}_{2}$ accumulation curve keeps growing for MMO-MCF after extensive electrolysis. In this case, the higher accumulation of $\mathrm{H}_{2} \mathrm{O}_{2}$ when using the $\mathrm{MMO}$ as an anode can be explained in terms of the higher production of other oxidants on the BDD surface, being the hydroxyl radical very important. These oxidants rapidly react with the $\mathrm{H}_{2} \mathrm{O}_{2}$ generated on the cathode, producing its decomposition. It is particularly important the reaction produced by the hydroxyl radical, which leads to the formation of the less powerful hydroperoxide radical as shown in Eq. (10) [20]. 
The higher production of $\mathrm{H}_{2} \mathrm{O}_{2}$ on the MCF cathode evidences the contribution of additional mechanisms for the more efficient use of oxygen on the cathodic surface. Thus, the improved performance of the modified cathode can be the result of its physical and chemical properties. The formation of a hydrophobic layer associated with the deposition of carbon black \& PTFE mixture prevents the complete cathode flooding. Therefore, porous would contain air and, consequently, a high concentration of oxygen regarding the oxygen levels present in the solution. This behavior enhances the presence of three-phase boundaries on the cathode, allowing the increase in the generation of hydrogen peroxide [23, 24, 29]. Contact angle analyses were carried for the unmodified CF and MCF materials in order to confirm the wetting properties of both cathodes. The unmodified carbon felt was very hydrophilic, and no contact angle value could be measured.

On the contrary, for the MCF, the contact angle was $116.2^{\circ}$ (Figure $2 \mathbf{b}$ ), which means a highly hydrophobic surface. Ren et al. showed that double modified graphite felts were more efficient for $\mathrm{H}_{2} \mathrm{O}_{2}$ production as compared to single modified and unmodified cathodes. The measure of contact angle indicated that unmodified material should be considered as hydrophilic, while after modification and double modification, both with carbon black and PTFE, the contact angles were $120^{\circ}$ and $138^{\circ}$, respectively [47]. These results agree with the observed here, and, as discussed above, they can explain the enhancement in the $\mathrm{H}_{2} \mathrm{O}_{2}$ production.

The data in Figure 2 also have relevance in the performance of the EAOPs based on the production of hydrogen peroxide. Thus, Yu et al. reported that the modified graphite felt cathode had much better performance on mineralization than the pristine cathode, indicating that the modified graphite felt was more efficient and cost-effective [23]. Also, Pérez et al., 
2018, reported that the removal of both maleic acid and acid orange 7 by EF using an unmodified CF cathode is low and slow.

On the other hand, the modified carbon felt produced by the deposition of carbon black and PTFE resulted in a fast removal, and high mineralization percentages of both molecules tested [32]. The modification of carbonaceous materials have been successfully reported in the literature without continuous aeration, and these studies have pointed out the continuous airflow as an insignificant factor in the removal efficiency of the pollutant $[23,48$, 49]. For example, Tian et al. [48], conducted electro-Fenton experiments using modified graphite felt for Rhodamine B degradation after $3 \mathrm{~h}$ electrolysis employing 0, 0.6, 1.0, and 1.6 L/min airflow rates and the results were $94.23,96.21,97.81$, and $98.17 \%$ of Rhodamine B removal, respectively. $\mathrm{Yu}$ et al. [23] investigated the accumulation of $\mathrm{H}_{2} \mathrm{O}_{2}$ at an $\mathrm{O}_{2}$ flow rate of $0,0.2,0.4$, and $0.6 \mathrm{~L} / \mathrm{min}$ and obtained stabilization in 470.2, 479.3, 493.5 and 505.1 $\mathrm{mg} / \mathrm{L}$ of $\mathrm{H}_{2} \mathrm{O}_{2}$, respectively. These findings suggested that after modification, hydrogen peroxide can be efficiently formed even without external aeration. Also, another study carried out the quantification of the hydroxyl radical formation during the electro-Fenton process and found very close values comparing experiments with and without continuous external aeration using the modified cathode [49]. These authors have explained this phenomenon based on the oxygen evolution reaction occurring at the anode surface, which was previously verified by the dissolved oxygen determination measurements. Thus, $\mathrm{O}_{2}$ as an anodic byproduct was found to be sufficient to ensure the $\mathrm{H}_{2} \mathrm{O}_{2}$ generation [23] what corroborates with our data. In this context, due to the superiority of the MCF over unmodified $\mathrm{CF}$, which is in good agreement with previous literature above mentioned, we selected this material as cathode for the subsequent experiments. Therefore, it is going to be studied the degradation of a model organic by different electrochemical advanced oxidation processes based on hydrogen peroxide. 


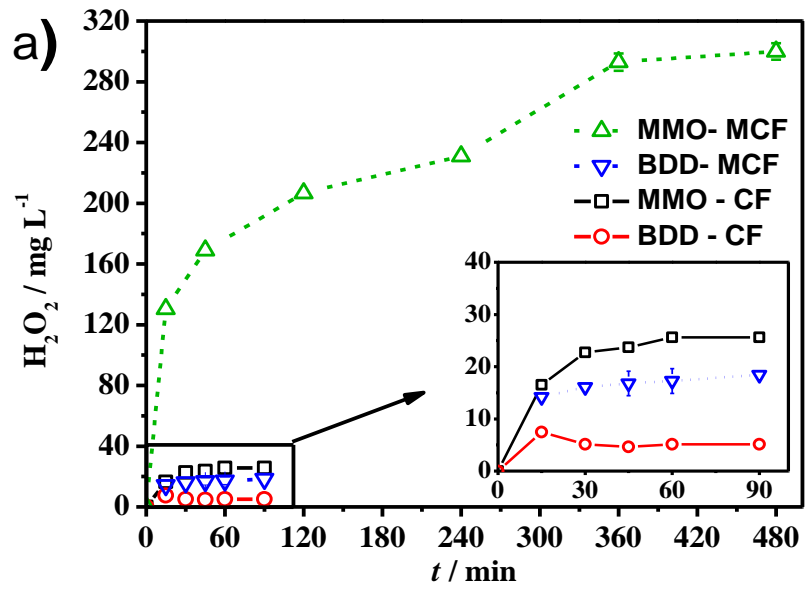

b)

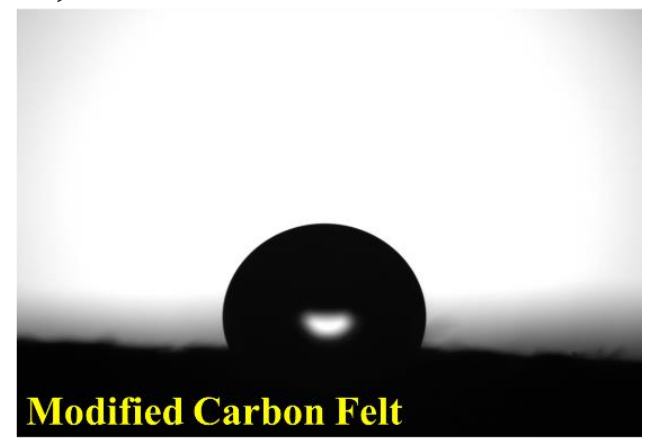

Figure 2. Evolution of $\mathrm{H}_{2} \mathrm{O}_{2}$ concentration during electrolysis of $\mathrm{O}_{2}$ in the electrochemical cell employing carbon felt $(\mathrm{CF})$ or modified carbon felt $(\mathrm{MCF})$ as cathode and MMO or BDD as the anode (Conditions: $\mathrm{V}: 0.15 \mathrm{~L},\left[\mathrm{Na}_{2} \mathrm{SO}_{4}\right]: 0.05 \mathrm{M}, \mathrm{pH} \sim 3.4$ ) (a) and contact angle of the MCF cathode (b).

Clopyralid degradation by different EAOPs. Degradation tests of synthetic wastes containing $100 \mathrm{mg} \mathrm{L}^{-1}$ of clopyralid were carried out using the combinations of electrodes MMO-MFC and BDD-MFC to evaluate the performance of anode materials on the degradation of clopyralid by EO- $\mathrm{H}_{2} \mathrm{O}_{2}$, EF, and PEF processes (Figure 3a). Photolysis of clopyralid was also performed for the sake of comparison. For this latter non-electrochemical experiment, the clopyralid concentration reduces only $8.7 \%$ after $8 \mathrm{~h}$ of irradiation. Conversely, total clopyralid removal is not attained by the $\mathrm{EO}-\mathrm{H}_{2} \mathrm{O}_{2}$ process during 8 $\mathrm{h}$ of treatment, regardless of the anode employed. The enhancement of the oxidation ability of the EF processes can result from the higher amounts of ${ }^{\bullet} \mathrm{OH}$ produced by the Fenton reaction. 
302

303

304

305

306

307

308

309

310

311

312

313

314

315

316

317

318

and clopyralid. In contrast, in the $\mathrm{EO}-\mathrm{H}_{2} \mathrm{O}_{2}$ with $\mathrm{MMO}$ or BDD anodes, the oxidation of clopyralid demands its transport towards the anode surface [50].

For PEF, the degradation rate improved in comparison to EF, which can be explicated in terms of the photolysis of Fe(III)-carboxylate species according to Eq. (11) [37, 39]. Likewise, when UVC light is applied, it favors the homolytic photolysis of $\mathrm{H}_{2} \mathrm{O}_{2}$ generating •OH homogeneously (Eq. (12)) [20]

$\mathrm{Fe}(\mathrm{OOCR})^{2+}+h v \rightarrow \mathrm{Fe}^{2+}+\mathrm{CO}_{2}+\mathrm{R}^{\bullet}$

$\mathrm{H}_{2} \mathrm{O}_{2}+h v \rightarrow 2^{\bullet} \mathrm{OH}$ 11

The obtained results showed that the degradation of clopyralid fitted well to pseudofirst-order reaction kinetic (Figure 3b). The observed kinetic constants are summarized in Table 1. The apparent rate constant for clopyralid removal $\left(k_{\text {clop }}\right)$ increased with increasing the number of all oxidants in the medium, especially the hydroxyl radicals generated by the EAOP, being of $0.025 \mathrm{~min}^{-1}$ for EO-MMO, $0.128 \mathrm{~min}^{-1}$ for EO-BDD, 1.106 for EF-MMO, $1.523 \mathrm{~min}^{-1}$ for EF-BDD, $1.601 \mathrm{~min}^{-1}$ for PEF-MMO and $3.00 \mathrm{~min}^{-1}$ for PEF-MMO. 


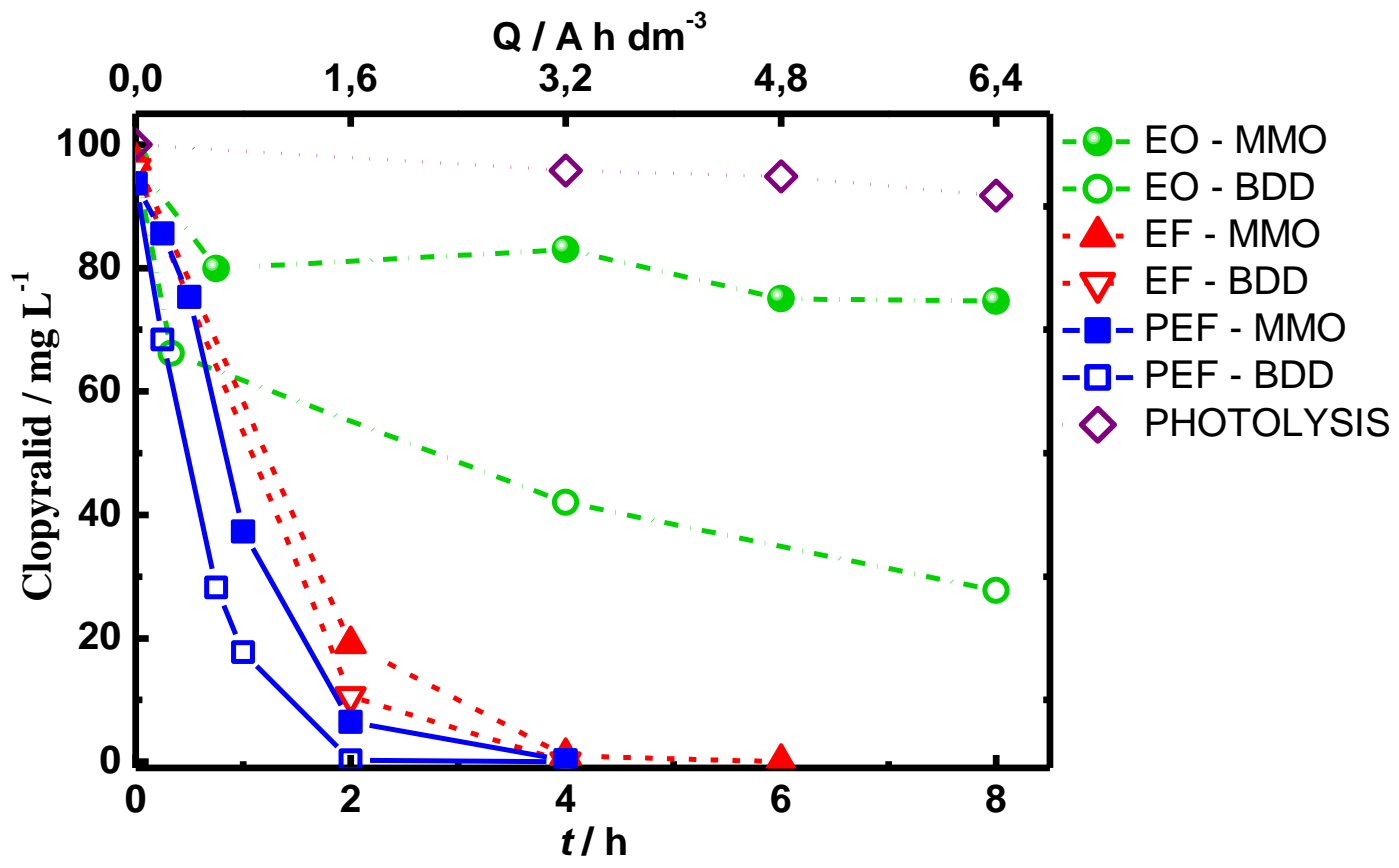

319

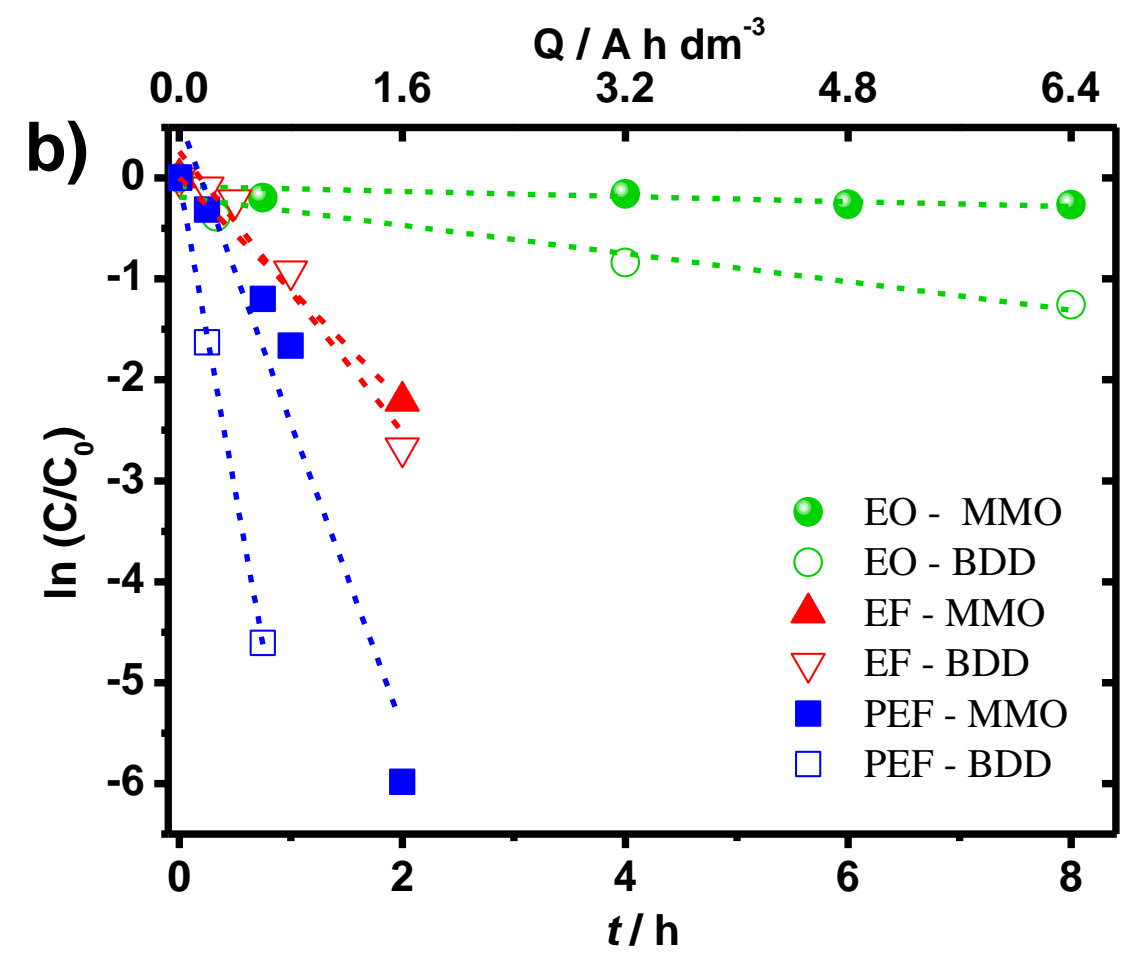

Figure 3. Clopyralid concentration decay as a function of the treatment time by different

322 EAOPs (a) and corresponding pseudo-first order kinetics (b). Conditions: Clopyralid: $100 \mathrm{mg}$ $323 \mathrm{~L}^{-1}\left[\mathrm{Na}_{2} \mathrm{SO}_{4}\right]: 0.05 \mathrm{M},\left[\mathrm{Fe}^{2+}\right]: 0.5 \mathrm{mM}, \mathrm{pH} \sim 3.4$; current: $0.15 \mathrm{~A}, \mathrm{~V}: 0.15 \mathrm{~L}$. 
Table 1. Clopyralid and TOC removal percentages and observed kinetic constants for

327 clopyralid decay by different EAOPs in $0.05 \mathrm{M} \mathrm{Na}_{2} \mathrm{SO}_{4}$.

\begin{tabular}{|c|c|c|c|c|c|}
\hline \multirow[t]{2}{*}{ Process } & \multirow{2}{*}{$\begin{array}{c}\begin{array}{c}\text { After } 4 \mathrm{~h} \text { of } \\
\text { treatment }\end{array} \\
\text { Clopyralid / \% }\end{array}$} & \multicolumn{2}{|c|}{$\begin{array}{c}\text { After } 8 \mathrm{~h} \text { of } \\
\text { treatment }\end{array}$} & \multirow{2}{*}{$\begin{array}{c}k_{\mathrm{clop}} \\
/ \min ^{-1}\end{array}$} & \multirow[t]{2}{*}{$\mathbf{R}^{2}$} \\
\hline & & Clopyralid / \% & TOC Removal / \% & & \\
\hline EO - MMO & 17.02 & 27.7 & $3.50 \pm 0.4$ & 0.025 & 0.50 \\
\hline EO - BDD & 58.0 & 74.6 & $65.0 \pm 1.99$ & 0.128 & 0.90 \\
\hline EF - MMO & 99.8 & 100 & $90.9 \pm 11.8$ & 1.106 & 0.94 \\
\hline EF - BDD & 99.9 & 100 & $100 \pm 0.032$ & 1.523 & 0.94 \\
\hline PEF - MMO & 100.0 & 100 & $100 \pm 0.396$ & 1.601 & 0.98 \\
\hline PEF - BDD & 100.0 & 100 & $95.0 \pm 0.002$ & 3.000 & 0.92 \\
\hline
\end{tabular}

Figure 4 depicts the TOC removal as a function of the EAOP employed. As can be seen, for $\mathrm{EO}-\mathrm{H}_{2} \mathrm{O}_{2}$, TOC reduced up to $65 \%$ and $3.5 \%$ when using a BDD and MMO anode, respectively. The higher mineralization observed for the BDD can be explained in terms of the very active attack of ${ }^{\bullet} \mathrm{OH}$ formed following Eq. (13) [51]. As well as, considering the well-known formation of other oxidants on the diamond surface, such as peroxosulfates, which in the presence of other oxidants can decompose and produce the very-powerful sulfate radical Eq. $(14,15)$.

$\mathrm{BDD}+\mathrm{H}_{2} \mathrm{O} \rightarrow \mathrm{BDD}\left(\bullet^{\bullet} \mathrm{OH}\right)+\mathrm{H}^{+}+\mathrm{e}^{-}$

$\mathrm{S}_{2} \mathrm{O}_{8}^{2}+\mathrm{Fe}^{2+} \rightarrow \mathrm{Fe}^{3+}+\left(\mathrm{SO}_{4}^{-}\right)+\left(\mathrm{SO}_{4}^{-}\right)^{\bullet}$

$\mathrm{S}_{2} \mathrm{O}_{8}{ }^{2}+\mathrm{UV} \rightarrow 2\left(\mathrm{SO}_{4}^{-}\right)^{\bullet}$

On the other hand, very low TOC removal occurs when using MMO anode. This behavior is expected due to the active nature of the MMO and the low amount of hydroxyls that are generated on its surface [52]. When $\mathrm{Fe}^{2+}$ is added to the solution, almost complete 
344 mineralization is seen, and BDD and MMO gave similar TOC decays, indicating that the 345 oxidation ability increased due to the high quantity of ${ }^{\bullet} \mathrm{OH}$ generated via Eq. (2) and Eq. (3)

$346[21,39]$. The slightly higher removal when BDD is employed is attributed to the additional 347 contribution of ${ }^{\bullet} \mathrm{OH}$ to remove intermediates in addition to the $\mathrm{BDD}\left({ }^{\bullet} \mathrm{OH}\right)$ [51]. Moreover, 348 when 9 W UV-C irradiates the solution, similar results are seen in terms of mineralization 349 (i.e., almost complete TOC removal). This behavior indicates that PEF leads to significant 350 improvements only on the contaminant removal, since the UVC light contributes to the direct 351 photolysis of the clopyralid molecule, then favoring the faster conversion seen in Figure 3. 352 However, the PEF process seems to have little effect for TOC removal, where ${ }^{\bullet} \mathrm{OH}$ radicals 353 formed from Fenton's Reaction (Eq. (2)) are the main oxidizing species under the experimental conditions used here.

At this point, it is also worthwhile to point out that irradiation of MMO356 $\mathrm{Ti} / \mathrm{Ru}_{0.3} \mathrm{Ti}_{0.7} \mathrm{O}_{2}$ can result in the formation of a positive hole $\left(\mathrm{h}^{+}\right)$and an electron $\left(\mathrm{e}^{-}\right)$. The oxidant character of the $\mathrm{h}^{+}$generates hydroxyl radicals $\left({ }^{\bullet} \mathrm{OH}\right)$ for the oxidation of the water adsorbed onto the anode surface that can oxidize the organic species near the anode surface. However, here, this effect must be included, although its influence is unnoticed since the amount of homogenous ${ }^{\bullet} \mathrm{OH}$ formed from Fenton's reaction is generated in much more amount than those produced photocatalytically. 


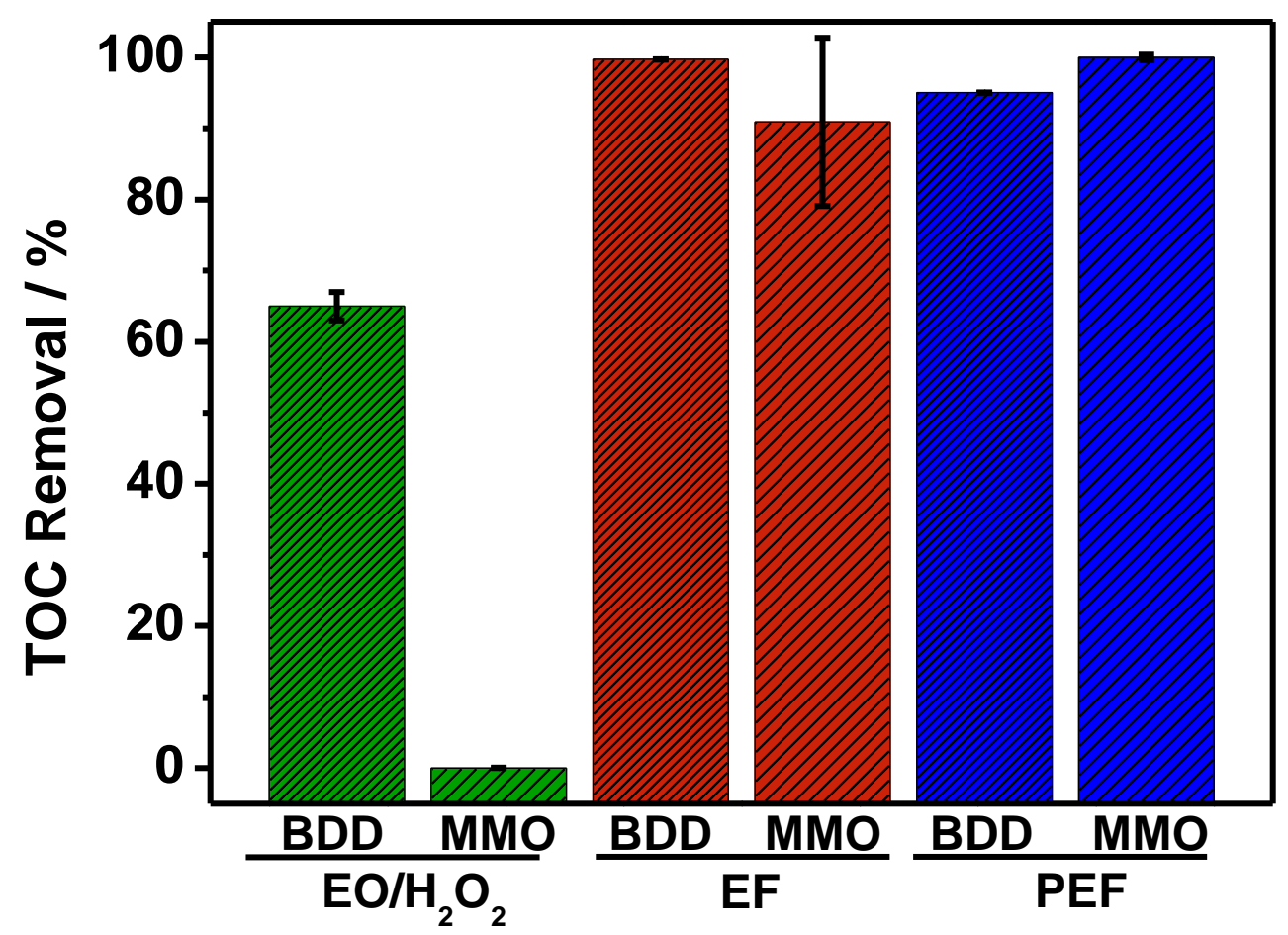

Figure 4. TOC removal after $8 \mathrm{~h}$ treatment by different EAOPs. Conditions: Clopyralid: 100 mg L ${ }^{-1} ;\left[\mathrm{Na}_{2} \mathrm{SO}_{4}\right]: 0.05 \mathrm{M},\left[\mathrm{Fe}^{2+}\right]: 0.5 \mathrm{mM}, \mathrm{pH} \sim 3.4$; current: $0.15 \mathrm{~A}, \mathrm{~V}: 0.15 \mathrm{~L}$.

As the final stage of the mineralization reaction, the observed residual organic load is due to the generated short-chain carboxylic acids (Figure 5), mainly oxalic acid. Other acids were found, including oxamic and maleic acid, but at a much lower concentration. Accumulation of oxalic acid is characteristic of many electrochemical advanced oxidation technologies. It is known that oxidation of oxalic acid in aqueous media is difficult. Then, its detection by the highly accurate by HPLC technique is justified, even when the system attains almost complete mineralization (Figure 4). Because of its good biodegradability and low toxicity, the combination of the EAOPs with a much cheaper biological treatment is recommended. 

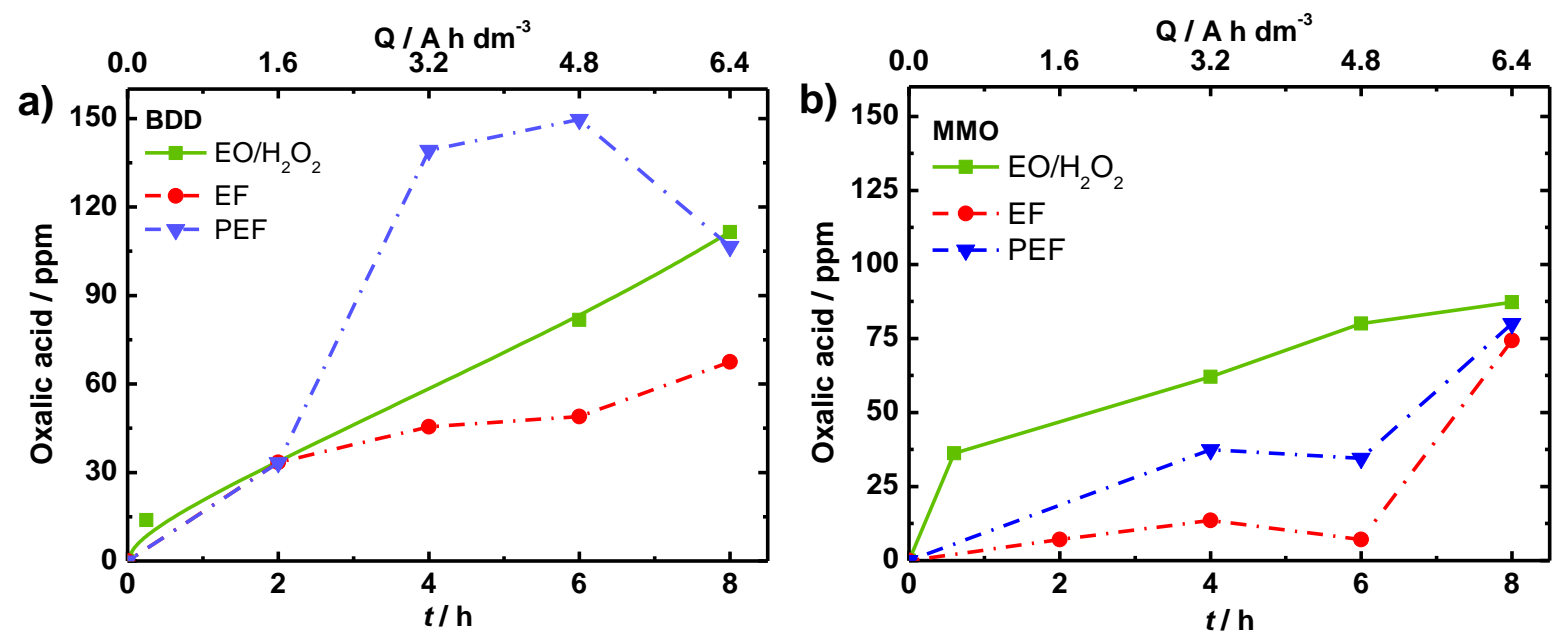

376

Figure 5. Evolution of oxalic acid concentration during $8 \mathrm{~h}$ treatment of clopyralid by different EAOPs using BDD (a) and MMO anode. Conditions: Clopyralid: $100 \mathrm{mg} \mathrm{L}^{-1}$; $\left[\mathrm{Na}_{2} \mathrm{SO}_{4}\right]: 0.05 \mathrm{M},\left[\mathrm{Fe}^{2+}\right]: 0.5 \mathrm{mM}, \mathrm{pH} \sim 3.4$; applied current: $0.15 \mathrm{~A}, \mathrm{~V}: 0.1 \mathrm{~L}$

To understand the possible routes by which clopyralid is converted to reaction intermediates, the by-products peaks were monitored over the tests by HPLC, and the primary intermediates were identified for each process studied. As a result, picolinic acid, 3picolinic acid, 6-picolinic acid other non-identified peaks were detected during clopyralid degradation through the different EAOPs (Figure 6), which is in agreement with literature and previous reports of our group. By comparing the influence of the process, an additional non-identified species at $5.1 \mathrm{~min}$ of retention time were observed only after EF/PEF-BDD, although at shallow concentration. 


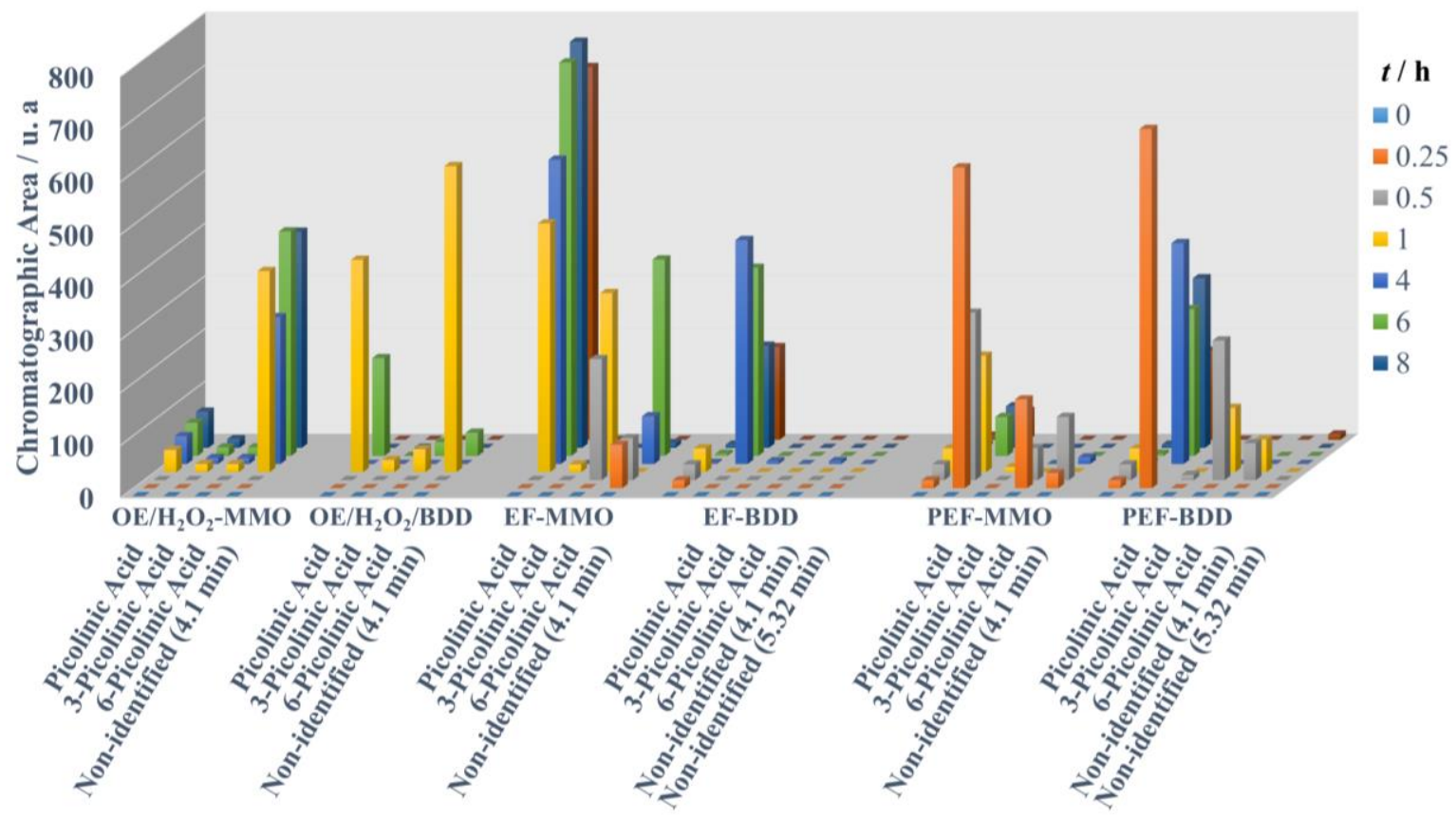

391 Figure 6. Area of the main identified peaks obtained during $8 \mathrm{~h}$ of treatment through different EAOPs, by HPLC using a C18 column.

The ion chromatography analysis indicates the formation of ammonium, chlorides, and nitrate ions (Table 2). It can be easily seen the formation of chloride ions until $6 \mathrm{~h}$ of treatment, followed by a decrease after $8 \mathrm{~h}$ of treatment (Figure 7). It is well-known that chlorine is a precursor for chlorate, and, in turn, chlorate is a precursor for perchlorate. Thus, the quantification and comparison of the formation of chlorine species are of interest [53]. This behavior can be correlated with the formation of chlorates and perchlorates that can be formed when high quantities of hydroxyl radicals are present in the bulk solution. Great attention should be paid regarding the formation of these species since they are reported to be hazardous [53, 54]. Note that when using BDD, the chloride ions are in much lower concentration than when MMO is employed. It can be a result of the additional hydroxyl radicals provided by the $\mathrm{BDD}\left({ }^{\bullet} \mathrm{OH}\right)$, which enables the conversion of $\mathrm{Cl}^{-}$ions to higher oxidation states, while for the $\mathrm{MMO}, \mathrm{Cl}_{2}$ at acid conditions is favored due to its active nature 
406

407

408

409

410

411

412

413

414

415

416

417

418

419

420

for chlorine evolution even at small quantities. Additionally, perchlorates were also detected for EAOPs employing BDD as the anode in the crescent order: $\mathrm{OE}<\mathrm{EF}<\mathrm{PEF}$.

On the other hand, no perchlorate was detected when working with the MMO.

Bergmann and coworkers showed that MMOs favored the formation of the chlorate, but perchlorate was not found when working with these anodes [53], which is in good agreement with the observed in this work. These findings are significant in order to ensure a safe method.
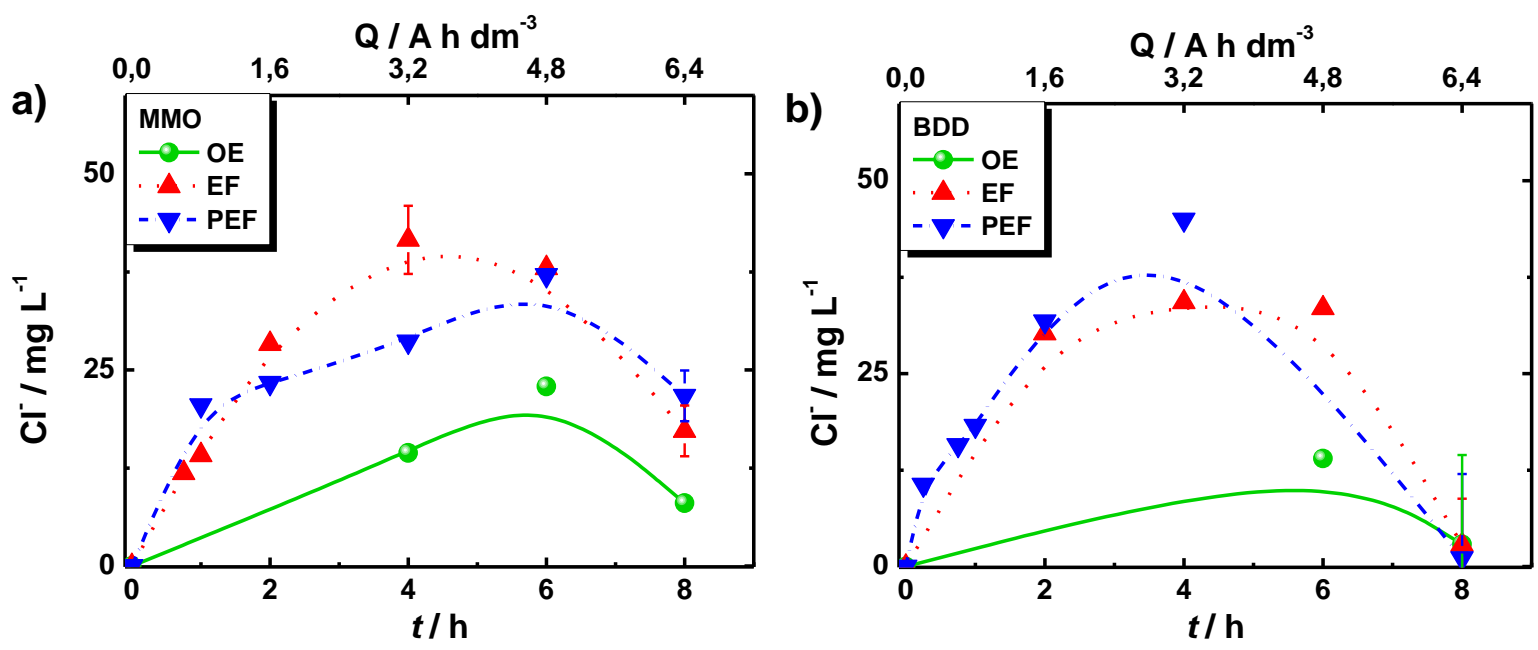

Figure 7. Evolution of inorganic chloride ions formed during degradation of the clopyralid by different EAOPs. Conditions: Clopyralid: $100 \mathrm{mg} \mathrm{L}^{-1}$; [ $\left.\mathrm{Na}_{2} \mathrm{SO}_{4}\right]$ : $0.05 \mathrm{M},\left[\mathrm{Fe}^{2+}\right]: 0.5 \mathrm{mM}$, $\mathrm{pH} \sim 3.4$; applied current: $0.15 \mathrm{~A}, \mathrm{~V}: 0.1 \mathrm{~L}$.

Table 2. Concentration of inorganic ions detected after $8 \mathrm{~h}$ treatment of $100 \mathrm{mg} \mathrm{L}^{-1}$ of clopyralid by different EAOPs. $\left[\mathrm{Na}_{2} \mathrm{SO}_{4}\right]: 0.05 \mathrm{M},\left[\mathrm{Fe}^{2+}\right]: 0.5 \mathrm{mM}, \mathrm{pH} \sim 3.4$; applied current: $0.15 \mathrm{~A}, \mathrm{~V}: 0.1 \mathrm{~L}$

\begin{tabular}{cccccc}
\hline \multicolumn{1}{c}{ Process } & $\begin{array}{c}{\left[\mathrm{NO}_{3}{ }^{-}\right]} \\
/ \mathrm{mg} \mathrm{L}^{-1}\end{array}$ & $\begin{array}{c}{\left[\mathrm{NH}_{4}^{+}\right]} \\
/ \mathrm{mg} \mathrm{L}^{-1}\end{array}$ & $\begin{array}{c}{\left[\mathrm{Cl}^{-}\right]} \\
/ \mathrm{mg} \mathrm{L}^{-1}\end{array}$ & $\begin{array}{c}{\left[\mathrm{ClO}_{3}^{-}\right]} \\
/ \mathrm{m} \mathrm{L} \mathrm{L}^{-1}\end{array}$ & $\begin{array}{c}{\left[\mathrm{ClO}_{4}^{-}\right]} \\
/ \mathrm{mg} \mathrm{L}^{-1}\end{array}$ \\
\hline EO - MMO & 3.54 & 0.78 & 8.04 & 11.49 & 0 \\
\hline EO - BDD & 9.109 & 1.51 & 2.9 & 16.25 & 14.1 \\
\hline EF - MMO & 4.894 & 3.40 & 17.23 & 7.27 & 0 \\
\hline
\end{tabular}




\begin{tabular}{lccccc}
\hline EF - BDD & 8.393 & 3.690 & 2.81 & 18.1 .5 & 35.33 \\
\hline PEF - MMO & 4.091 & 3.239 & 21.7 & 4.50 & 0 \\
\hline PEF - BDD & 4.399 & 1.865 & 1.11 & 16.4 & 38.32 \\
\hline
\end{tabular}

421

422

423

424

425

426

427

428

429

430

To investigate the synergistic effect of combined electrochemical oxidation and Fenton's reagent, and the further addition of UVC irradiation, the synergy coefficients for the removal of clopyralid, as a function of the anode material were calculated according to Eq. (4). As a result, Figure $\mathbf{8}$ shows a much more pronounced effect of the iron catalyst when the MMO is employed, showing synergy effect 4-times higher. This result agrees to that previously stated for the higher accumulation of $\mathrm{H}_{2} \mathrm{O}_{2}$ for the $\mathrm{EO} / \mathrm{H}_{2} \mathrm{O}_{2}-\mathrm{MMO}$ and the $\mathrm{MCF}$ cathode. It means that the catalytic amount of iron reacts rapidly with hydrogen peroxide to produce the powerful hydroxyl radical in the bulk solution.

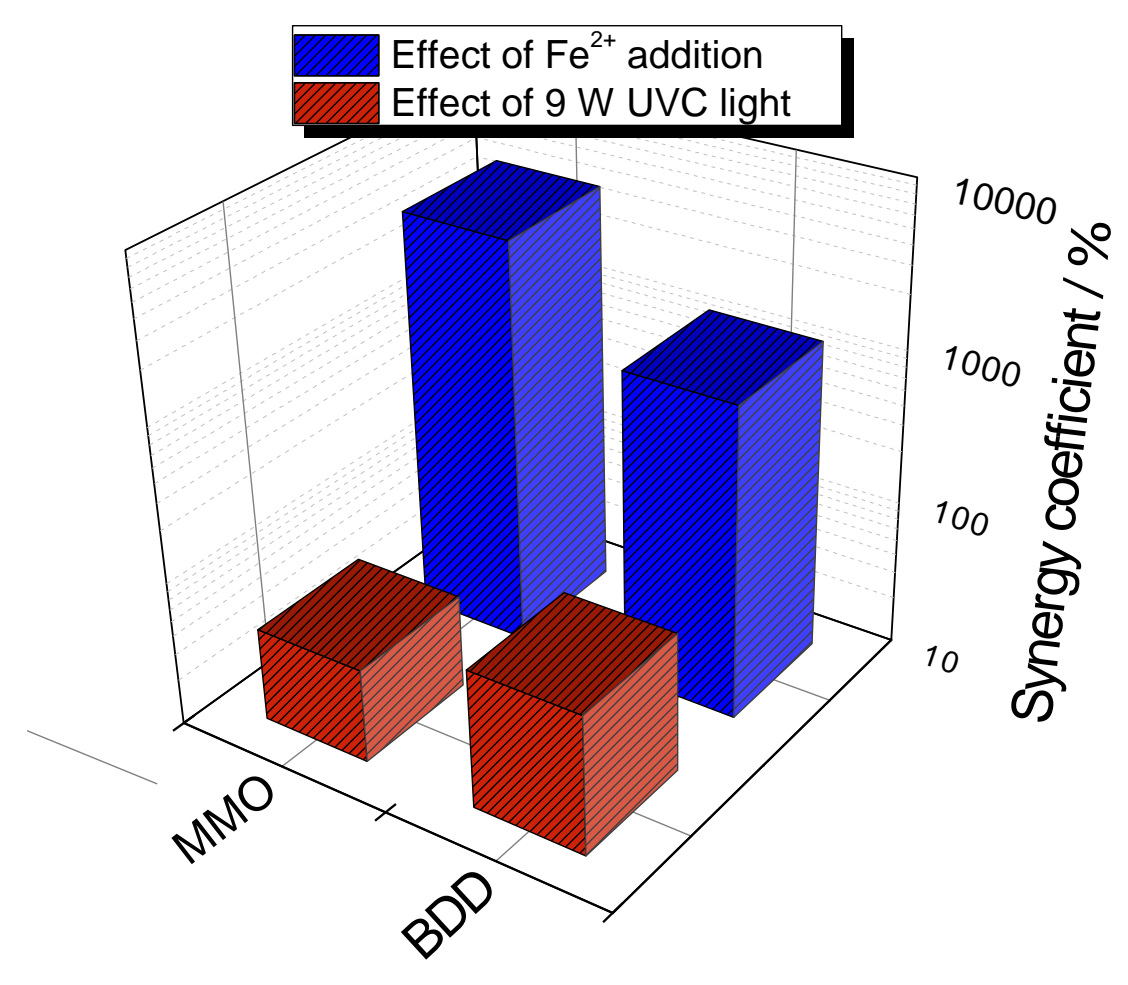

432 Figure 8. The synergistic coefficient for clopyralid removal considering the Effect of $\mathrm{Fe}^{2+}$ 433 addition ( $\square$ ) and the effect of 9 W UVC light ( $\square$ ). 
On the contrary, the BDD anode showed a lower synergy effect due to: (1) the

436

437

438

439

440

441

442

443

444

445

446

447

448

449

450

451

452

453

454

455

456

457

458 generation of less reactive $\mathrm{HO}_{2}{ }^{\bullet}$, according to Eqs. (9), and (2) the lower amount of hydrogen peroxide electrogenerated, as compared to the MMO anode. The much higher synergy coefficient found for the MMO (Figure 8) agrees with data in Figure 3, although a slightly higher removal rate is seen for the process with BDD. It occurs because the presence of a catalytic amount of iron provokes the activation of a large amount of $\mathrm{H}_{2} \mathrm{O}_{2}$ accumulated for the MMO, increasing the kinetics 44.24 times comparing with the EO. For the BDD, a higher kinetics rate is already observed before the activation of $\mathrm{H}_{2} \mathrm{O}_{2}\left(0.128 \mathrm{~min}^{-1}\right)$, which means that the additional contribution of $\bullet \mathrm{OH}$ from Fenton's reaction is less pronounced (increase in 11.9 times in the kinetics).

Regarding the irradiation of UVC light, a positive synergistic effect is seen for both MMO and BDD (41.5\% and $81.7 \%$, respectively). This effect indicates that irradiation of UVC light is less important than the addition of an iron catalyst, in the clopyralid removal. Nevertheless, the values found point out a clear contribution of photolysis for molecule breakage into intermediates, which are more easily attacked by the hydroxyl radicals formed homogeneously, allowing more significant removals for both anodes.

The results obtained were used to estimate the energy consumptions per unit of TOC (EC $\mathrm{TOC}_{\mathrm{T}}$ (Figure 9). As seen, this parameter seems to depend on both the process applied and anode material used. The values found evidenced $\mathrm{EC}_{\mathrm{TOC}}$ decreased drastically when the iron catalyst was added to the EO system, especially for the EO-MMO. Also, the $\mathrm{EC}_{\mathrm{TOC}}$ for the EF and PEF with the MMO anode (1.63 and $1.23 \mathrm{~kW} \mathrm{~h}\left(\mathrm{~g} \mathrm{TOC}^{-1}\right)$, respectively) were up to 2-fold lower than the respective processes with the BDD anode $\left(2.56\right.$ and $2.5 \mathrm{~kW} \mathrm{~h}\left(\mathrm{~g} \mathrm{TOC}^{-}\right.$ ${ }^{1}$ ), respectively). The MMO anode displays lower energy consumption than the BDD, likely due to the improved conductivity of the catalytic coating. Whereas the improved indirect 
oxidation occurring in bulk is related to the activation of oxidants through the catalytic decomposition of the $\mathrm{H}_{2} \mathrm{O}_{2}$, as mentioned before.

However, the energy spent does not present a significant difference when comparing EF and PEF processes, regardless of the anode material. Montes and coworkers [42] evaluated the energy consumption per unit TOC mass of tebuthiuron (TBT) for the UV/chlorine process. These authors found that for UVC lamps of low pressure (5 $\mathrm{W}$ and 9 W), values of energy consumption varied around 3 and $10 \mathrm{~kW} \mathrm{~h} \mathrm{~g}^{-1}$ for TBT and TOC removal, respectively. While for high-pressure lamps ( $80 \mathrm{~W}$ and $125 \mathrm{~W}$ ), those values increased for higher than 10 and $200 \mathrm{~kW} \mathrm{~h} \mathrm{~g}^{-1}$ for TBT and TOC removal, respectively. Thus, they suggest that the use of low-pressure lamps is preferable and sufficient to attain oxidation and mineralization rates when compared to the individual electrochemical oxidation. Likewise, Moreira et al. [55] conducted a comparative study on different EAOPs using BDD or Pt as the anode to remove trimethoprim in $7.0 \mathrm{~g} \mathrm{~L}^{-1} \mathrm{Na}_{2} \mathrm{SO}_{4}$. They found that PEF-BDD with $6 \mathrm{~W}$ UVA lamp exhibited slightly faster pollutant removal that the PEF-Pt one, while the solar PEF-BDD and the solar PEF-Pt presented energy consumption of $1.2 \mathrm{~kW}$ $\mathrm{h} \mathrm{m}^{-3}$ and $0.9 \mathrm{~kW} \mathrm{~h} \mathrm{~m}^{-3}$, respectively. These results indicated a more efficient application $\mathrm{Pt}$ coated anode, cheaper than BDD. These findings agree with those observed in this work for PEF.

Another previous study reported by our research group [33] showed the feasibility of the photoelectrolysis for clopyralid removal using a laser-made $\mathrm{Ti} / \mathrm{Ru}_{0.3} \mathrm{Ti}_{0.7} \mathrm{O}_{2}$ anode. From an in-depth comparison with the BDD anode, the MMO anode showed a better performance in the presence of chloride ions. The homolysis of $\mathrm{HClO}$ into chlorine and hydroxyl radicals explained this behavior, which was responsible for attaining $53.6 \%$ of mineralization after 6.4 $\mathrm{A} \mathrm{h} \mathrm{L}^{-1}$ of applied charge. Remarkably, the same anode here employed in combination with the MCF was capable of accomplishing almost complete mineralization in the PEF 
process. Moreover, in terms of the primary intermediates, our work stands out for the complete removal of the intermediates detected.

Here, the slightly lower values of energy consumption found for PEF (with 9 W UVC light) as compared with EF, regardless of the anode material, can be of interest as a feasible option to treat effluents contaminated with chlorinated compounds such as clopyralid. This fact brings up to consider that the use of cheaper material, such as the MMO used in this work, is a good alternative for both EF and PEF since it yields similar efficiencies in clopyralid and TOC removal using BDD anode.

Moreover, additional advantages, such as lower energy consumption similar or even lower than values reported in the literature for EAOPs at similar conditions [55, 56], and the reduced cost of synthesis and time for the production of these anodes [34] makes the use of this material suitable and quite attractive.

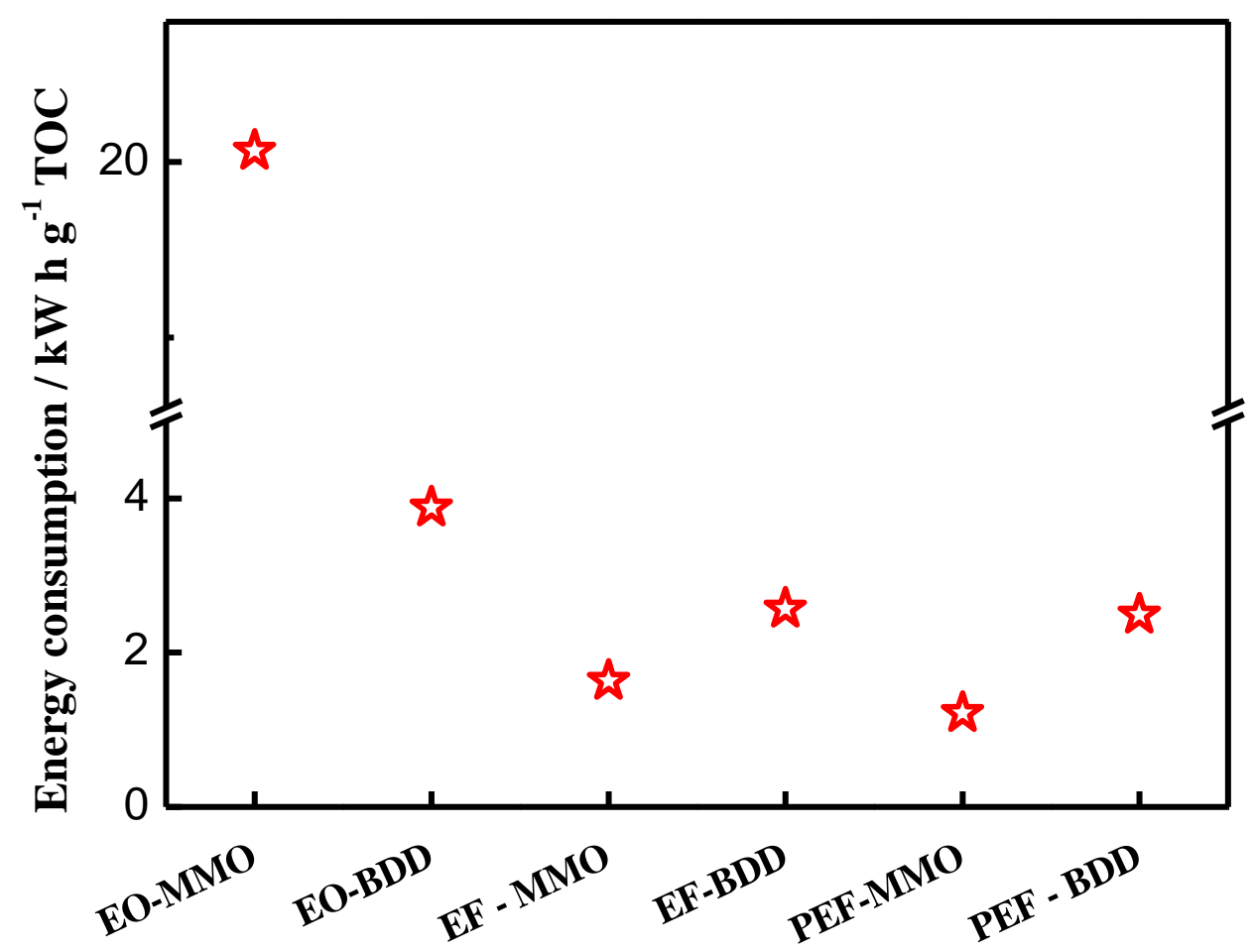

Figure 9. Energy consumption calculated for the different EAOPs studied according to the anode material employed after $8 \mathrm{~h}$ of electrolysis. 
4. Conclusions

From this work, the following conclusions can be drawn:

\section{Conflicts of interest}


There are no conflicts to declare.

526

527

\section{Acknowledgments}

528 Financial support from the Agencia Estatal de Investigación through project CTM201676197-R (AEI/FEDER, UE) is gratefully acknowledged. This study was also financed by the

Coordenação de Aperfeiçoamento de Pessoal de Nível Superior (CAPES) finance codes

(88882.365552/2018-01 and 88881.187890/2018-01) The authors also acknowledge the

financial support from the Brazilian agencies CNPq (305438/2018-2, 310572/2016-9, and

311856/2019-5) and FAPITEC/SE. We also thank Prof. Dr. Ronaldo Santos da Silva from the

Federal University of Sergipe for the equipment for the $\mathrm{CO}_{2}$ laser synthesis.

535

536

\section{References}

[1] M. A. Rodrigo, N. Oturan, M.A. Oturan, Electrochemically assisted remediation of pesticides in soils and water: a review, Chemical Reviews, 114(17) (2014) 8720-8745.

[2] D.V. Šojić, V.B. Anderluh, D.Z. Orčić, B.F.J. Abramović, Photodegradation of clopyralid in $\mathrm{TiO}_{2}$ suspensions: Identification of intermediates and reaction pathways, Journal of Hazardous Materials 168(1) (2009) 94-101.

[3] M. Rodríguez, M. Muñoz-Morales, J. Perez, C. Saez, P. Cañizares, C. Barrera-Díaz, M.A. Rodrigo, Toward the Development of Efficient Electro-Fenton Reactors for Soil Washing Wastes through Microfluidic Cells, Industrial \& Engineering Chemistry Research 57(31) (2018) 10709-10717.

[4] M. Carboneras, M. Rodrigo, P. Canizares, J. Villaseñor, F.J.S. Fernandez-Morales, Electroirradiated technologies for clopyralid removal from soil washing effluents, Separation and Purification Technology (2019) 115728.

[5] M. Muñoz-Morales, C. Sáez, P. Cañizares, M. A. Rodrigo, Enhanced electrolytic treatment for the removal of clopyralid and lindane, Chemosphere (2019), 132-138.

[6] M.J.M. de Vidales, M.P. Castro, C. Saez, P. Cañizares, M.A. Rodrigo, Radiation-assisted electrochemical processes in semi-pilot scale for the removal of clopyralid from soil washing wastes, Separation and Purification Technology 208 (2019) 100-109.

[7] G.O.S. Santos, I.M.D. Gonzaga, K.I.B. Eguiluz, G.R. Salazar-Banda, C. Saez, M.A. Rodrigo, Improving biodegradability of clopyralid wastes by photoelectrolysis: The role of the anode material, Journal of Electroanalytical Chemistry , 864, (2020) 114084. 
[8] D.B. Miklos, C. Remy, M. Jekel, K.G. Linden, J.E. Drewes, U.J.W.R. Hübner, Evaluation of advanced oxidation processes for water and wastewater treatment-a critical review, 139 (2018) 118-131.

[9] R. Dewil, D. Mantzavinos, I. Poulios, M.A. Rodrigo, New perspectives for advanced oxidation processes, Journal of Environmental Management, 195 (2017) 93-99.

[10] F.C. Moreira, R.A. Boaventura, E. Brillas, V.J.P. Vilar, Electrochemical advanced oxidation processes: a review on their application to synthetic and real wastewaters, Applied Catalysis B Environmental, 202 (2017) 217-261.

[11] I. Sirés, E. Brillas, M.A. Oturan, M.A. Rodrigo, M. Panizza, Electrochemical advanced oxidation processes: today and tomorrow. A review, Environmental Science and Pollution Research, 21(14) (2014) 8336-8367.

[12] F. Sopaj, M.A. Rodrigo, N. Oturan, F.I. Podvorica, J. Pinson, M.A. Oturan, Influence of the anode materials on the electrochemical oxidation efficiency. Application to oxidative degradation of the pharmaceutical amoxicillin, Chemical Engineering Journal, 262 (2015) 286-294.

[13] M. Shestakova, M. Sillanpää, Electrode materials used for electrochemical oxidation of organic compounds in wastewater, Reviews in Environmental Science and Bio/Technology,16(2) (2017) 223-238.

[14] I. Moraleda, N. Oturan, C. Saez, J. Llanos, M.A. Rodrigo, M.A. Oturan, A comparison between flow-through cathode and mixed tank cells for the electro-Fenton process with conductive diamond anode, Chemosphere, 238 (2020) 124854.

[15] B. Garza-Campos, D. Morales-Acosta, A. Hernández-Ramírez, J. Guzmán-Mar, L. Hinojosa-Reyes, J. Manríquez, E.J. Ruiz-Ruiz, Air diffusion electrodes based on synthetized mesoporous carbon for application in amoxicillin degradation by electro-Fenton and solar photo electro-Fenton, Electrochimica Acta, 269 (2018) 232-240.

[16] C. Espinoza, J. Romero, L. Villegas, L. Cornejo-Ponce, R. Salazar, Mineralization of the textile dye acid yellow 42 by solar photoelectro-Fenton in a lab-pilot plant, Journal of Hazardous Materials, 319 (2016) 24-33.

[17] S. Garcia-Segura, J. Anotai, S. Singhadech, M.-C. Lu, Enhancement of biodegradability of otoluidine effluents by electro-assisted photo-Fenton treatment, Process Safety and Environmental Protection 106 (2017) 60-67.

[18] F. Souza, R. Rocha, N. Ferreira, M. Rodrigo, M. Lanza, Effects of coupling hybrid processes on the treatment of wastewater containing a commercial mixture of diuron and hexazinone herbicides, Electrochimica Acta, 328 (2019) 135013. 
[19] A. Thiam, E. Brillas, J.A. Garrido, R.M. Rodríguez, I. Sirés, Routes for the electrochemical degradation of the artificial food azo-colour Ponceau 4R by advanced oxidation processes, Applied Catalysis B: Environmental, 180 (2016) 227-236.

[20] A. Xu, E. Brillas, W. Han, L. Wang, I. Sirés, On the positive effect of UVC light during the removal of benzothiazoles by photoelectro-Fenton with UVA light, Applied Catalysis B: Environmental 259 (2019) 118127.

[21] F.C. Moreira, J. Soler, M.F. Alpendurada, R.A. Boaventura, E. Brillas, V.J. Vilar, Tertiary treatment of a municipal wastewater toward pharmaceuticals removal by chemical and electrochemical advanced oxidation processes, Water Research 105 (2016) 251-263.

[22] J. Meijide, J. Gómez, M. Pazos, M. Sanromán, Degradation of thiamethoxam by the synergetic effect between anodic oxidation and Fenton reactions, Journal of Hazardous Materials, 319 (2016) 43-50.

[23] F. Yu, M. Zhou, X. Yu, Cost-effective electro-Fenton using modified graphite felt that dramatically enhanced on $\mathrm{H}_{2} \mathrm{O}_{2}$ electro-generation without external aeration, Electrochimica Acta 163 (2015) 182-189.

[24] M. Zhou, Q. Yu, L. Lei, G. Barton, Electro-Fenton method for the removal of methyl red in an efficient electrochemical system, Separation and Purification Technology 57(2) (2007) 380-387.

[25] V.M. Vasconcelos, C. Ponce-de-León, S.M. Rosiwal, M.R. Lanza, Electrochemical Degradation of Reactive Blue 19 Dye by Combining Boron-Doped Diamond and Reticulated Vitreous Carbon Electrodes, ChemElectroChem 6(13) (2019) 3516-3524.

[26] C. Trellu, N. Oturan, F.K. Keita, C. Fourdrin, Y. Pechaud, M.A. Oturan, Regeneration of activated carbon fiber by the electro-Fenton process, Environmental Science \& Technology 52(13) (2018) 7450-7457.

[27] S. Zhao, T. Guo, X. Li, T. Xu, B. Yang, X. Zhao, Carbon nanotubes covalent combined with graphitic carbon nitride for photocatalytic hydrogen peroxide production under visible light, Applied Catalysis B: Environmental 224 (2018) 725-732.

[28] J.R. Steter, E. Brillas, I. Sirés, Solar photoelectro-Fenton treatment of a mixture of parabens spiked into secondary treated wastewater effluent at low input current, Applied Catalysis B: Environmental 224 (2018) 410-418.

[29] J. Pérez, A. Galia, M. Rodrigo, J. Llanos, S. Sabatino, C. Sáez, B. Schiavo, O. Scialdone, Effect of pressure on the electrochemical generation of hydrogen peroxide in undivided cells on carbon felt electrodes, Electrochimica Acta 248 (2017) 169-177. 
[30] W.R. Barros, T. Ereno, A.C. Tavares, M.R. Lanza, In situ electrochemical generation of hydrogen peroxide in alkaline aqueous solution by using an unmodified gas diffusion electrode, ChemElectroChem 2(5) (2015) 714-719.

[31] J. Moreira, V.B. Lima, L.A. Goulart, M.R. Lanza, Electrosynthesis of hydrogen peroxide using modified gas diffusion electrodes (MGDE) for environmental applications: Quinones and azo compounds employed as redox modifiers, Applied Catalysis B: Environmental 248 (2019) 95-107.

[32] J. Pérez, S. Sabatino, A. Galia, M. Rodrigo, J. Llanos, C. Sáez, O. Scialdone, Effect of air pressure on the electro-Fenton process at carbon felt electrodes, Electrochimica Acta 273 (2018) 447-453.

[33] G.O.S. Santos, K.I.B. Eguiluz, G.R. Salazar-Banda, C. Saez, M.A. Rodrigo, Photoelectrolysis of clopyralid wastes with a novel laser-prepared $\mathrm{MMO}-\mathrm{RuO}_{2} \mathrm{TiO}_{2}$ anode, Chemosphere 244 (2020) 125455.

[34] G. O. S. Santos, L.R.A Silva, Y.G. Alves, R.S. Silva, K.I.B. Eguiluz, G.R. Salazar-Banda, Enhanced stability and electrocatalytic properties of $\mathrm{Ti} / \mathrm{Ru}_{\mathrm{x}} \mid \mathrm{r}_{1-} \mathrm{XO}_{2}$ anodes produced by a new laser process, Chemical Engineering Journal 355 (2019) 439-447.

[35] A. Özcan, N. Oturan, Y. Şahin, M.A. Oturan, Electro-Fenton treatment of aqueous clopyralid solutions, International Journal of Environmental and Analytical Chemistry 90(3-6) (2010) 478486.

[36] M.B.C. Contreras, F. Fourcade, A. Assadi, A. Amrane, F.J. Fernandez-Morales, Electro Fenton removal of clopyralid in soil washing effluents, Chemosphere 237 (2019) 124447.

[37] A.M.S. Solano, S. Garcia-Segura, C.A. Martínez-Huitle, E. Brillas, Degradation of acidic aqueous solutions of the diazo dye Congo Red by photo-assisted electrochemical processes based on Fenton's reaction chemistry, Applied Catalysis B: Environmental 168 (2015) 559-571.

[38] X. Florenza, A.M.S. Solano, F. Centellas, C.A. Martínez-Huitle, E. Brillas, S. Garcia-Segura, Degradation of the azo dye Acid Red 1 by anodic oxidation and indirect electrochemical processes based on Fenton's reaction chemistry. Relationship between decolorization, mineralization and products, Electrochimica Acta 142 (2014) 276-288.

[39] S. Garcia-Segura, Á.S. Lima, E.B. Cavalcanti, E. Brillas, Anodic oxidation, electro-Fenton and photoelectro-Fenton degradations of pyridinium-and imidazolium-based ionic liquids in waters using a BDD/air-diffusion cell, Electrochimica Acta 198 (2016) 268-279.

[40] S. Cotillas, M.J.M. de Vidales, J. Llanos, C. Sáez, P. Cañizares, M.A. Rodrigo, Electrolytic and electro-irradiated processes with diamond anodes for the oxidation of persistent pollutants and disinfection of urban treated wastewater, Journal of Hazardous Materials 319 (2016) 93-101.

[41] N. Flores, E. Brillas, F. Centellas, R.M. Rodríguez, P.L. Cabot, J.A. Garrido, I. Sirés, Treatment of olive oil mill wastewater by single electrocoagulation with different electrodes and sequential 
electrocoagulation/electrochemical Fenton-based processes, Journal of Hazardous Materials 347 (2018) 58-66.

[42] I.J. Montes, B.F. Silva, J.M. Aquino, On the performance of a hybrid process to mineralize the herbicide tebuthiuron using a DSA ${ }^{\circledR}$ anode and UVC light: a mechanistic study, Applied Catalysis B: Environmental 200 (2017) 237-245.

[43] E. Brillas, I. Sirés, M.A. Oturan, Electro-Fenton process and related electrochemical technologies based on Fenton's reaction chemistry, Chemical Reviews 109(12) (2009) 6570-6631.

[44] E. Brillas, R.M. Bastida, E. Llosa, J. Casado, Electrochemical destruction of aniline and 4chloroaniline for wastewater treatment using a carbon-PTFEO 2 -fed cathode, Journal of the Electrochemical Society 142(6) (1995) 1733-1741.

[45] E. Petrucci, A. Da Pozzo, L. Di Palma, On the ability to electrogenerate hydrogen peroxide and to regenerate ferrous ions of three selected carbon-based cathodes for electro-Fenton processes, Chemical Engineering Journal 283 (2016) 750-758.

[46] G. Kolyagin, V. Kornienko, Kinetics of hydrogen peroxide accumulation in electrosynthesis from oxygen in gas-diffusion electrode in acidic and alkaline solutions, Russian Journal of Applied Chemistry 76(7) (2003) 1070-1075.

[47] G. Ren, M. Zhou, M. Liu, L. Ma, H. Yang, A novel vertical-flow electro-Fenton reactor for organic wastewater treatment, Chemical Engineering Journal 298 (2016) 55-67.

[48] J. Tian, J. Zhao, A.M. Olajuyin, M.M. Sharshar, T. Mu, M. Yang, J. Xing, Effective degradation of rhodamine B by electro-Fenton process, using ferromagnetic nanoparticles loaded on modified graphite felt electrode as reusable catalyst: in neutral $\mathrm{pH}$ condition and without external aeration, Environmental Science and Pollution Research 23(15) (2016) 15471-15482.

[49] A. Xu, W. Han, J. Li, X. Sun, J. Shen, L. Wang, Electrogeneration of hydrogen peroxide using $\mathrm{Ti} / \mathrm{IrO}_{2}-\mathrm{Ta}_{2} \mathrm{O}_{5}$ anode in dual tubular membranes Electro-Fenton reactor for the degradation of tricyclazole without aeration, Chemical Engineering Journal 295 (2016) 152-159.

[50] M.B. Carboneras, P. Cañizares, M.A. Rodrigo, J. Villaseñor, F.J. Fernandez-Morales, Improving biodegradability of soil washing effluents using anodic oxidation, Bioresource technology 252 (2018) 1-6.

[51] N. Barhoumi, H. Olvera-Vargas, N. Oturan, D. Huguenot, A. Gadri, S. Ammar, E. Brillas, M.A. Oturan, Kinetics of oxidative degradation/mineralization pathways of the antibiotic tetracycline by the novel heterogeneous electro-Fenton process with solid catalyst chalcopyrite, Applied Catalysis B: Environmental 209 (2017) 637-647. 
2

[52] T. Panakoulias, P. Kalatzis, D. Kalderis, A. Katsaounis, Electrochemical degradation of Reactive Red 120 using DSA and BDD anodes, Journal of Applied Electrochemistry 40(10) (2010) 17591765.

[53] M. Bergmann, J. Rollin, A. Koparal, Chlorate and perchlorate-new criterions for environmentally-friendly processes in Advanced Oxidation, Water Practice and Technology 5(2) (2010), 2102-2107.

[54] M.H. Bergmann, J. Rollin, T. lourtchouk, The occurrence of perchlorate during drinking water electrolysis using BDD anodes, Electrochimica Acta 54(7) (2009) 2102-2107.

[55] F.C. Moreira, S. Garcia-Segura, R.A. Boaventura, E. Brillas, V.J. Vilar, Degradation of the antibiotic trimethoprim by electrochemical advanced oxidation processes using a carbon-PTFE air-diffusion cathode and a boron-doped diamond or platinum anode, Applied Catalysis B: Environmental 160 (2014) 492-505.

[56] B.R. Garza-Campos, J.L. Guzmán-Mar, L.H. Reyes, E. Brillas, A. Hernández-Ramírez, E.J. Ruiz-Ruiz, Coupling of solar photoelectro-Fenton with a BDD anode and solar heterogeneous photocatalysis for the mineralization of the herbicide atrazine, Chemosphere 97 (2014) 26-33.

(1) 